\title{
HUBUNGAN MOTIVASI INTRINSIK DENGAN KEPATUHAN DIET PASIEN DIABETES MELITUS TIPE II DI PUSKESMAS RANOTANA WERU
}

\author{
Frysty P.I Mamesah \\ Max Runtuwene \\ Mario Katuuk \\ Program Studi Ilmu Keperawatan Fakultas Kedokteran \\ Universitas Sam Ratulangi \\ Email : fristymamesah@gmail.com
}

\begin{abstract}
Diabetes Mellitus is a chronic disease which caused by the dysfunction of beta cells in producing the insulin. One of any interventions that can be applied is a medical nutrition therapy (diet). Non-adherence to this therapy may caused complications. Intrinsic Motivation is one of any factors that takes an important role in adherence to diet, because it is driven by internal rewards from within the individual. The aim: of this study is to know the relation relation between intrinsic motivation and dietary compliance of diabetes mellitus type II in Ranotana Weru's Health Public Center. Number of Samples: 83 respondents are used as the sample of this study. Research method: this research design is uses a cross-sectional; descriptive-correlational method with the purposive sampling approach. The result: shows that $p$ values $=0,000$ with the significant values $95 \%$ equals to $p=0,000<p=0,005$ for the motivation and dietary adherence of Diabetes Mellitus. Conclusion: this study shows that there is a relation between intrinsic motivation and dietary adherence of Diabetes Mellitus Type II in Public Health Center of Ranotana Weru.
\end{abstract}

Keyword : Diabetes Mellitus, Intrinsic Motivation, Dietary Adherence

\begin{abstract}
Abstrak: Diabetes Melitus (DM) merupakan penyakit menahun. Salah satu penatalaksaan Diabetes Melitus ialah terapi nutrisi medis (diet). Faktor yang sangat mempegaruhi kepatuhan diet ialah motivasi intrinsik karena motivasi intrinsik merupakan motivasi yang timbul dari diri sendiri dan rangsangan dari lingkungan. Tujuan: Tujuan penelitian ini ialah untuk mengetahui hubungan motivasi intrinsik dan kepatuhan diet diabetes melitus tipe II di puskesmas ranotana weru manado. Jumlah sampel: jumlah sampel yang peneliti gunakan pada penelitian ini adalah 83 responden. Desain Penelitian: Desain penelitian ini adalah penelitian cross-sectional yang bersifat deskriptif korelatif dengan teknik pendekatan purposive sampling. Hasil Penelitian: Hasil penelitian ini menunjukan bahwa nilai $p=0,000$ dengan nilai kemaknaan 95\% yang berarti $p=0,00<p=0,005$ untuk motivasi dan kepatuhan diet diabetes mellitus. Kesimpulan: Dapat disimpulkan bahwa dalam penelitian ini adanya hubungan yang signifikan antara motivasi intrinsik dengan kepatuhan diet diabetes mellitus tipe II.
\end{abstract}

Kata Kunci: Diabetes Melitus, Motivasi Intrinsik, Kepatuhan Diet 


\section{PENDAHULUAN}

Diabetes Melitus merupakan penyakit menahun yang disebabkan oleh kegagalan sel beta pankreas dalam memproduksi hormon insulin (Anies, 2018). Data International Diabates Federation (IDF) (2015) menyatakan bahwa prevalensi penyandang DM di dunia pada tahun 2015 sebanyak 415 juta jiwa dan diperkirakan akan bertambah pada tahun 2040 dengan kenaikan yang signifikan yakni sebanyak 642 juta jiwa penyandang DM. Indonesia sendiri masuk dalam 10 besar Negara yang memiliki penyandang DM, dan menempati urutan ke 7 dari ke 10 Negara dengan jumlah yang sangat banyak yaitu 10 juta jiwa penyandang DM. Prevalensi DM di Indonesia pada 2013 yakni sebanyak $6.9 \%$ sedangkan pada tahun 2018 mengalami kenaikkan sebanyak 8,5 \% (Riset Kesehatan Dasar, 2018). Prevalensi di Sulawesi Utara sendiri yaitu sebanyak $2,4 \%$ atau dengan jumlah 40.772 jiwa dan pada tahun 2018 naik sekitar 2,9\% sampai dengan $3.0 \%$ dan menempati urutan ke 4 menurut provinsi yang paling banyak penyandang DM (RISKESDAS, 2018).

Penatalaksaan DM terdiri dari 4 pilar penatalaksaan yaitu Edukasi, latihan jasmani, terapi farmakologis dan terapi nutisi medis (diet) (PERKENI, 2015). Terapi nutrisi medis (Diet) DM merupakan suatu metode yang digunakan untuk mengatur asupan nutrisi pasien agar tetap terpenuhi dan tidak mengakibatkan gula didalam darah meningkat sehingga perlu adanya pengaturan jadwal, jenis, dan jumlah makanan sebagai acuan diet DM (Indrawati dkk 2012). Kepatuhan diet bertujuan untuk dapat mengontrol kadar gula didalam darah agar terwujud kualitas hidup yang lebih baik bagi penyandang DM, kepatuhan diet DM perlu diperhatikan karena jika tidak diperhatikan akan berujung pada komplikasi-komplikasinya (Muflihatin \& Komala, 2016). Komplikasi DM antara lain luka yang sulit sembuh, penyakit jantung, ulkus diabetes, katarak dan lain sebagainya, salah satu faktor yang mempegaruhi kepatuhan diet ialah Motivasi Intrinsik (Fatimah, 2015). Motivasi intrinsik merupakan keyakinan dari dalam diri seseorang bahwa ia sanggup untuk melakukan tugas atau tanggung jawab tertentu yang harus ia lakukan atau keyakinan yang datang dari dalam diri sendiri karena ada dorongan dari lingkungan (Risty \& Isnaini 2017). Penelitian yang dilakukan oleh Muflihatin \& Komala (2016) pada 42 responden DM dengan hasil $64,3 \%$ memiliki motivasi sedangkan hanya $35,7 \%$ yang tidak termotivasi dan yang memiliki kepatuhan terhadap diet sebanyak $61,9 \%$ dan yang tidak patuh $38,1 \%$ dengan hasil adanya hubungan antara motivasi dan kepatuhan diet.

Berdasarkan data awal yang didapatkan di Puskesmas Ranotana Weru Manado, prevalensi pada 3 bulan terakhir kejadian DM pada bulan Agustus tahun 2018 yaitu sekitar 45 penyandang DM, pada bulan September tahun 2018 mengalami kenaikan yaitu sekitar 68 penyandang dan pada bulan Oktober yaitu sekitar 37 penyandang DM. Wawancara yang telah dilakukan pada 10 orang narasumber, 7 narasumber mengatakan bahwa mereka mengetahui diet yang baik namun tidak melakukannya karena bosan dengan diet yang dilakukan dan ditambah dengan kebiasaan hidup orang manado yang dikenal dengan suka makan-makan dalam porsi yang besar dan terbiasa untuk tidak pilih-pilih makanan dalam artian semua bisa di makan sehingga mereka sulit untuk mematuhi diet DM dan 3 narasumber mengatakan bahwa melakukan diet karena tidak ingin mendapat komplikasikomplikasinya dan disertai dengan dukungan keluarga yang ada sehingga ia semangat untuk melakukannya. Berdasarkan uraian dari diatas, dapat dirumuskan pertanyaan peneliti sebagai berikut: apakah ada hubungan motivasi intrinsik dengan kepatuhan diet DM tipe II di wilayah kerja Puskesmas Ranotana Weru? 


\section{METODE PENELITIAN}

Penelitian ini termasuk dalam jenis penelitian kuantitatif dengan menganalisis gambaran hubungan antara kedua variabel yaitu variabel independen (motivasi intrinsik) dan variabel dependen (kepatuhan diet). Penelitian ini menggunakandesain penelitian cross sectional. Penelitian ini dilaksanakan di Kecamatan Wanea pada bulan Desember 2018 - Maret 2019. ). Populasi dalam penelitian ini adalah seluruh pasien diabetes melitus tipe 2 di Puskesmas Ranotana Weru dengan jumlah 90 responden. Pengambilan sampel menggunakan teknik purposive sampling dengan rumus slovin maka didapatkan jumlah sampel minimal 74 responden, untuk mengantisipasi hilangnya unit sampel maka dilakukan korelasi dengan mengunakan rumus drop out sehingga didapatkan sampel 84 responden. Instrumen pengumpulan data yang digunakan dalam penelitian ini adalah lembar kuesioner untuk variabel independent. Kuesioner tersebut telah pernah di gunakan oleh Lestari (2012), lembar kuesioner motivasi intrinsik terdiri dari 8 pertanyaan. Dan dikategorikan "ya" diberi nilai 3 "kadang-kadang" diberi nilai 2 dan "tidak" diberi nilai 1. Pemberian Skor pada motivasi intrinsik ditentukan dengan menggunakan rumus Cut Off Point, sehingga didapatkan hasil jika skor > 16 dinyatakan baik dan jika skor $\leq 16$ dinyatakan tidak baik.

Instrumen pengumpulan data variabel dependen. Kuesioner tersebut sebelumya sudah pernah digunakan oleh Karim (2012), lembar kuesioner kepatuhan diet terdiri dari 18 pertanyaan. Dan dikategorikan "sering" diberi nilai 3, "jarang " diberi nilai 2 dan "tidak pernah" diberi nilai 1. Pemberian Skor pada kepatuhan diet ditentukan dengan menggunakan rumus Cut Off Point, sehingga didapatkan hasil jika skor > 35 dinyatakan baik dan jika skor $\leq 35$ dinyatakan tidak baik Pengolahan data yang diperoleh dari hasil penelitian ini diolah secara manual dengan mengelompokkan hasil wawancara dan observasi kemudian dilakukan penghitungan skor dan dianalisis menggunakan uji statistik melalui sistem komuterisasi dengan beberapa tahap yaitu editing, coding, entering, cleaning (Notoatmodjo, 2012). Analisa bivariat dalam penelitian ini yaitu untuk mengetahui hubungan motivasi intrinsik dengan kepatuhan diet pasien diabetes melitus tipe II di Puskesmas Ranotana Weru. Peneliti menggunakan uji statistik Chi Squaredengan tingkat kemaknaan 95\% $(\alpha=0,05)$.

\section{HASIL dan PEMBAHASAN}

\section{Analisa Univariat}

Tabel 1.Distribusi Responden Berdasarkan Motivasi Intrinsik

\begin{tabular}{ccc}
\hline Motivasi Intrinsik & N & \% \\
\hline Baik & 59 & 71.7 \\
Tidak Baik & 24 & 28.9 \\
\hline Total & $\mathbf{8 3}$ & $\mathbf{1 0 0}$ \\
\hline
\end{tabular}

Sumber : Data Primer 2019

Hasil penelitian menunjukan bahwa dari 83 responden didapati sebagian besar memiliki motivasi intrinsik yang baik yaitu sebesar 59 orang dengan persentasi $71 \%$ sedangkan 24 dengan persentasi $28.9 \%$ diantarnya tidak memiliki motivasi intrinsik yang baik, yang didapatkan dari hasil penelitian mayoritas responden mematuhi anjuran diet yang diberikan, selalu terdorong untuk mematuhi anjuran diet yang diberikan dan mengurangi porsi makanan sehari-hari. Sejalan dengan penelitian yang dilaukan Sugendi dkk (2015) mengemukakan bahwa responden yang memiliki motivasi yang baik adalah sebanyak 37 orang dari 48 sampel.

Penelitian yang telah dilakukan di oleh Yulia (2015) di Puskesmas Kudungmundu memperoleh hasil dimana responden dengan Motivasi yang baik yaitu sebanyak 25 orang dari 48 sampel yang ada. penelitian yang dilakukan di Pekalongan oleh Indrawati dkk (2012) 
menyatakan bahwa tingkat motivasi rendah sebanyak 29 orang dengan persentasi $54,7 \%$ dari 53 responden, sehingga tidak sejalan dengan penelitian yang telah dilakukan oleh peneliti dan ditambah dengan hasil-hasil penelitian yang lain.

Berdasarkan beberapa penelitian dan teori sebelumnya peneliti berasumsi bahwa tingkat motivasi intrinsik yang baik dapat menjadi dorongan bagi setiap diri manuasia sehingga peneliti menyimpulkan bahwa sebagian besar penyandang DM yang ada di Indonesia memiliki tingkat motivasi intrinsik yang baik, Sejalan dengan penelitian yang telah peneliti lakukan di Kota Manado khususnya di Puskesmas Ranotana Weru sebanyak 59 responden memiliki motivasi Intrinsik yang baik, karena motivasi intrinsik merupakan dorongan dalam diri manusia dalam rangka memenuhi kebutuhan hidupnya sehingga motivasi Intrinsik sangat mempegaruhi seseorang dalam menjalankan diet sejalan dengan teori yang di kemukakan oleh Notoadmodjo (2010).

Tabel 2.Distribusi Berdasarkan Kepatuhan Diet

\begin{tabular}{ccc}
\hline Kepatuhan Diet & $\mathbf{N}$ & $\mathbf{\%}$ \\
\hline patuh & 56 & 78.3 \\
Tidak Patuh & 18 & 21.7 \\
\hline Total & $\mathbf{8 3}$ & $\mathbf{1 0 0}$ \\
\hline
\end{tabular}

Sumber : Data Primer 2019

Hasil penelitian menunjukan dari 83 responden yang ada, 56 responden memiliki tingkat kepatuhan diet DM yang patuh dengan persentase $78,3 \%$ dan 18 diantaranya tidak mematuhi diet DM dengan persentase $21,7 \%$. Kepatuhan diet dalam penelitian ini didapatkan mayoritas responden, makan tepat waktu sesuai anjuran tenaga kesehatan, memakanmakanan sesuai anjuran tenaga kesehatan, secara rutin mengontrol kadar gula darah ke Puskesmas dan lain sebagainya. Kepatuhan adalah perilaku individu misalnya minum obat, mematuhi diet, atau melaukukan perubahan gaya hidup sesuaidengan anjuran terapi dari tenaga kesehatan guna mencapai taraf kesehatan yang lebih baik, Kepatuhan merupakan istilah yang digunakan seseorang untuk menjelaskan ketaatan seseorang dalam menjalankan diet yang telah dianjurkan (Tumenggung, 2013). Faktor-faktor yang dapat mempengaruhi kepatuhan diantaranya, motivasi klien untuk sembuh, tingkat perubahan gaya hidup yang dibutuhkan, persepsi keparahan masalah kesehatan, nilai dan upaya untuk mengurangi ancaman penyakit, tingkat gangguan penyakit, kebiasaan atau budaya dan tingkat kepuasan (Kozier, 2010).

Penelitian ini sejalan dengan penelitian yang telah dilakukan oleh Susanti dkk (2013) yang mengatakan dari 25 responden yang ada $20 \quad(80 \%)$ responden diantaranya mematuhi diet DM yang diberikan, penelitian lain juga yang telah dilakukan oleh Wiardani dan Moviana (2014) menyatakan bahwa 62,9\% responden patuh terhadap diet DM yang diberikan. Penelitian yang dilakukan oleh Senuk dkk (2013) menyatakan bahwa $53,6 \%$ memiliki tingkat kepatuhan yang patuh terhadap diet DM yang diberikan.

\section{Analisa Bivariat}

Tabel 3. Hubungan Motivasi Intrinsik Dengan Kepatuhan Diet DM

\begin{tabular}{|c|c|c|c|c|c|c|c|}
\hline \multirow{3}{*}{$\begin{array}{l}\text { Motivasi } \\
\text { Intrinsik }\end{array}$} & \multicolumn{4}{|c|}{ Kepatuhan Diet } & \multirow{2}{*}{\multicolumn{2}{|c|}{ Total }} & \multirow{3}{*}{$\begin{array}{l}P- \\
v a l \\
u e\end{array}$} \\
\hline & \multicolumn{2}{|c|}{$\begin{array}{l}\text { Tidak } \\
\text { Patuh } \\
\end{array}$} & \multicolumn{2}{|c|}{ Patuh } & & & \\
\hline & $\mathrm{n}$ & $\%$ & $\mathrm{n}$ & $\%$ & $\mathrm{n}$ & $\%$ & \\
\hline Tidak Baik & 12 & 14,5 & 12 & 14.5 & 24 & 100 & \\
\hline Baik & 6 & 7.2 & 53 & 63,9 & 59 & 100 & 000 \\
\hline Total & 65 & 56,5 & 50 & 43,5 & 115 & 100 & \\
\hline
\end{tabular}

Sumber : Data Primer 2019

Hasil analisis uji bivariat didapatkan hasil dari 83 responden, responden yang memiliki motivasi intrinsik baik dan patuh terhadapat diet DM sebanyak 53 penyandang DM, dimana mereka terdorong untuk menjalankan diet dan melakukan diet DM seperti makan tepat waktu, memakan makanan sesuai anjuran dokter dan lain sebagainya. Kemudian responden yang memiliki motivasi intrinsik yang baik dan tidak 
patuh sebanyak 6 penyandang DM, dimana mereka terdorong untuk melakukan diet namun jarang mengkonsumsi makan seperti buah dan sayur, makanan yang banyak mengandung vitamin, jarang mengontrol gula darah. Selanjutnya yang memiliki motivasi intrinsik yang tidak baik dan patuh, dimana mereka misalnya merasa tidak mematuhi anjuran diet yang diberikan namun mereka makan tepat waktu dan mengkomsumsi buah-buahan dan sayuran dan memaikai gula penganti. Sebanyak 12 penyandang DM yang memiliki motivasi intrinsik yang tidak baik dan tidak patuh, dimana mereka tidak terdorong untuk melakukan anjuran diet dan tidak makan tepat waktu, tidak mengkomsumsi buah dan sayuran dan lain sebagainya. Hasil uji hipotesis dengan menggunakan uji chi - square dengan tingkat kepercayaan 95\% $(\alpha 0,05)$, untuk mencari hubungan antara motivasi intrinsik Dengan kepatuhan diet DM didapatkan hasil expected count lebih dari 5 dan $\mathrm{p}-$ value $=0,000$ yang artinya terdapat hubungan yang signifikan antara motivasi intrinsik dengan kepatuhan diet DM di Puskesmas Ranotana Weru Manado. Syarat uji chi-square terpenuhi sehingga tidak dilanjutkan dengan uji fisher dan smirnov.

Hasil penelitian ini sesuai dengan teori pendukung yang mengatakan salah satu faktor yang mempegaruhi diet DM adalah motivasi intrinsik (Amin \& Haryanti 2018). Teori yang dikemukakan oleh Notoadmodjo (2010) mengatakan faktor-faktor yang dapat mempegaruhi kepatuhan diantarnya adalah Motivasi Intrinsik, karena Motivasi intrinsik merupakan salah satu faktor yang memberikan pengaruh terhadap kepatuhan pasien, semakin tinggi motivasi pasien maka semakin besar juga peluang untuk mematuhi diet yang dianjurkan (Silva, 2013), motivasi intrinsik adalah keadaan dalam pribadi seorang yang mendorong untuk melakukan kegiatan tertentu guna mencapai tujuan yang diinginkan (mengontrol gula dalam darah) (Marquis \&
Huston, 2010). Study yang telah Yulia (2015) didapatkan hasil bahwa salah satu faktor yang dapat mempegaruhi diet adalah Motivasi yang didalam termasuk motivasi intrinsik. Hasil penelitian ini juga sesuai dengan penelitian yang telah dilaukan oleh Toruan dkk (2018) menyatakan bahwa pasien yang memiliki motivasi diri tinggi lebih besar peluang untuk mematuhi anjuran diet yang diberikan pada pasien DM, dan pasien yang memiliki motivasi yang rendah maka akan lebih cenderung untuk mengabaikan anjuran diet yang diberikan. Penelitian yang menunjukan hasil yang sama juga adalah penelitian yang dilakukan oleh Risty dan Isnaini (2017) yang menyatakan bahwa ada hubungan yang signifikan antara Motivasi Intrinsik dan kepatuhan Diet DM, dengan hasil penyandang DM mematuhi diet yang diberikan karena memiliki motivasi yang baik dan yang tidak memiliki motivasi yang baik maka tidak akan mematuhi anjuran diet yang diberikan.

Penelitian lain juga yang telah dilakukan oleh Muslihatin dan Komala (2016) menyatakan bahwa adanya hubungan yang signifikan antara motivasi dengan kepatuhan diet, dengan hasil semakin besar motivasi yang dimiliki seseorang maka semakin besar juga kepatuhan diet yang akan dimiliki. Sebaliknya semakin rendah motivasi yang dimiliki makan akan semakin sedikit peluang untuk mematuhi diet DM. Penelitian ini tidak sejalan dengan penelitian yang dilakukan oleh Pujiastuti (2016) menyatakan bahwa tidak ada hubungan yang signifikan antara motivasi dengan kepatuhan diet DM dimana mayoritas responden memiliki tingkat motivasi yang rendah, penelitian ini sejalan dengan penelitian yang dilakukan oleh Indrawati dkk (2013) dimana dari 53 responden $29(54,7 \%)$ memiliki motivasi yang rendah. Peneliti berasumsi bahwa responden yang memiliki motivasi intrinsik yang baik akan lebih mematuhi anjuran diet yang diberikan oleh tenaga kesehatan dan responden yang tidak 
memiliki motivasi intrinsik yang baik maka ia tidak akan mematuhi anjuran diet DM yang diberikan oleh tenaga kesehatan. Sehingga dapat disimpulkan kepatuhan diet yang baik dapat dilaksanakan ketika penyandang DM memiliki motivasi untuk mengontrol gula didalam darah. Motivasi yang tepat adalah motivasi intrinsik, karena motivasi intrinsik merupakan dorongan dari dalam diri seseorang misalnya untuk mencapai derajat kesehatan yang lebih baik dan dapat dipegaruhi oleh lingkungan luar seperti dukungan keluarga, dukungan tenaga kesehatan dan lain sebagainya, sejalan dengan teori yang di kemukakan oleh Amin \& haryanti (2018). Sehingga sangat erat kaitannya antara motivasi intrinsik dengan kepatuhan diet karena ketika motivasi intrinsik telah terbentuk maka pasien akan mematuhi anjuran diet yang diberikan (Silva, 2013).

\section{SIMPULAN}

Berdasarkan hasil pengumpulan data, pengolahan data dan pembahasan teori dalam penelitian ini ,maka dapat disimpulkan: responden yang berada di Puskesmas Ranotana Weru memiliki motivasi intrinsik yang baik, responen yang berada di Puskesmas Ranotana Weru mematuhi anjuran diet DM yang diberikan dan terdapat hubungan yang signifikan antara Motivasi Intrinsik Dengan Kepatuhan Diet Pasien DM tipe II Di Puskesmas Ranotana Weru

\section{DAFTAR PUSTAKA}

Anies. (2018). Penyakit Degeneratif. Yogyakarta: Ar-Ruzz Media

Amin, S \& Haryanti, R. (2018). Pola Asuh Orang Tua Dalam Motivasi Belajar Anak. Yogyakarta: CV Budi Utama.

Fatimah, N. R. (2015). Diabetes Melitus Tipe 2. Medical Faculty, Lampung University. Vol.4 No5.

IDF. (2015). Diabetes Atlas (Seventh Edition). International Diabetes
Federation. Diakses pada 03 oktober 2018

Indarwati, D., Riskiana., Rusmariana, A. \& Hartanti D. R. (2012). Hubungan Motivasi Dengan Kepatuhan Diet Diabetes Melitus Pada Pasien Diabetes Melitus Di Desa Tangkil Wilayah Kerja Puskesmas Kedungwuni II Kabupaten Pekalongan. Program Studi Keperawatan STIKES Pekalongan

Kozier. (2010). Buku Ajar Praktik Keperawatan Klinis. Edisi 5. Jakarta : EGC

Karim, H, A. (2013). Proporsi Dan Gambaran Kepatuhan Diet Terhadap Terapi Diet Pada Pasien Diabetes Melitus Tipe 2 Di RSUD Kota Cilegon Periode Januari-Mei 2013. (Skripsi Ilmiah). PSIK Fakultas Kedokteran Dan Ilmu Kesehatan Universitas Islam Negeri Syarif Hidayatullah

Lestari, T. S. (2012). Hubungan Psikososial dan Penyuluhan Gizi dengan Kepatuhan Diet Pasien Diabetes Mellitus Tipe 2 Rawat Jalan di RSUP Fatmawati Tahun 2012.

Muflihatin, K. S \& Komala (2016). Hubungan Motivasi Dengan Kepatuhan Diet Diabetes Pada Pasien Diabetes Mellitus Tipe II Di Puskesmas Sempaja Samarinda.

Marquis, B. L. \& Huston, C. J. (2010). Kepemimpinan dan manajemen keperawatan : teori dan aplikasi, (Ed. 4). Jakarta : EGC

Notoatmodjo, P.D.S. (2010). Ilmu Perilaku Kesehatan. Jakarta: PT Rineka Cipta.

Notoatmodjo, .P.D.S. (2012). Metodologi Penelitian Kesehatan. Jakarta : Rineka Cipta

PERKENI (2015). Konsensus Pengelolaan dan Pencegahan Diabetes Mellitus 
tipe 2 di Indonesia. Diakses pada 07 oktober 2018

Pujiastuti, E .(2016). Hubungan Motivasi Dan Kepatuhan Diet Pada Pasien Diabetes Melitus Tipe II Di Poli Klinik Penyakit Dalam RSUD Dr. Solehadi Prinajegoro Sragen.

Risti, N. K. \& Isnaeni N.F. (2017). Hubungan Motivasi Diri Dan Pengetahuan Gizi Terhadap Kepatuhan Diet Dm Pada Pasien Diabetes Mellitus Tipe II Rawat Jalan Di Rsud Karanganyar. Program Studi Ilmu Gizi Fakultas Ilmu Kesehatan Universitas Muhammadiyah.

Riset Kesehatan Dasar. (2018). Hasil Utama Riskesdas 2018.

Sugandi., Hasneli., \& Bayhakki .(2017). Faktor-Faktor Yang Mepengaruhi Kepatuhan Diet Diabetes Pada Pasien Diabetes Mellitus Tipe 2. Program Studi Ilmu Keperawatan Universitas Riau.

Susanti, M. Lina., Sulistyarini, T. 2013. Dukungan Keluarga MeningkatkanKepatuhan Diet Pasien Diabetes Melitus Di Ruang Rawat Inap RS Baptis Kediri. Jurnal STIKES Volume 6, No. 1, Juli 2013. STIKES RS. Baptis Kediri

Silva, J. (2013). Motivation for selfcare in older women with heart disease and diabetes : A balancing act.

Senuk, A., Supit, W., Onibala, F. 2013. Hubungan Pengetahuan Dan dukungan Keluarga Dengan Kepatuhan Menjalani Diet Diet Diabetes Melitus Di Poliklinik RSUD Kota Tidore Kepulauan Provinsi Maluku Utara. Ejournal keperawatan (e-Kp) Volume 1, Nomor 1 Agustus 2013 Hlm 1-7. Fakultas Kedokteran Universitas Sam Ratulangi Manado
Tumenggung, I. (2013). Hubungan Dukungan Sosial Keluarga Dengan Kepatuhan Diet Pasien Hipertensi di RSUD Toto Kabila Kabupaten Bone Bolango. Politeknik Kesehatan Gorontalo.

Toruan., Karim., \& Woferst. (2018). Hubungan Motivasi Diri Dengan Kepatuhan Diet Pada Penderita Diabetes Melitus Tipe 2. Fakultas Keperawatan Universitas Riau.

Wiardani, K. N., Moviana, Y. 2014. Hubungan antara tingkat kepatuhan diet dengan kadar gula darah pada penderita DM tipe 2 di RSUO Sanglah Denpasar. Poltekes Denpasar.

Yulia, S. (2015). Faktor-faktor yang mempegaruhi kepatuhan dalam menjalnakan diet pada penderita Diabetes mellitus tipe 2. Jurusan ilmu kesehatan masyarakat fakultas ilmu keolaragaan. 